\title{
THE RELATIONSHIP BETWEEN FREIGHT REVENUES AND VESSEL DISPOSAL DECISIONS
}

\author{
Gemiyi Söküme Gönderme Kararlarıyla Navlun Gelirleri Arasındaki İlişki
}

\section{Abdullah AÇIK ${ }^{1}$ \& Sadık Özlen BAŞER ${ }^{2}$}

\begin{abstract}
Anahtar Kelimeler: BDI, navlun gelirleri, gemi söküm,

iktisadi dalgalanmalar
\end{abstract}

Jel Kodları:

C01, F44, L16

Keywords:

$\mathrm{BDI}$, freight revenues, demolition,

business cycles

Jel Codes:

C01, F44, L16

\begin{abstract}
Ship demolition market helps to balance over supply in shipping market. Some factors accelerate and some factors slow down this process. Freight revenues are one of the most important factor that directly affect this process. Because even the old and obsolete ships can survive and carry out their operations profitably in buoyant market with high freight rates. In this context, this study aims to contribute existing literature by presenting an econometric analysis of the relationship between freight revenues and ship disposal decisions. Total tonnage sent to the demolition and Baltic Dry Index (BDI) variables are chosen, and annual data between 1985 and 2015 is used in the model. BDI is selected as a representative of freight revenues due to data constraint. Total tonnage sent to the scrapping is taken as a result of the decision to send ships to disposal. Correlation and regression analysis are conducted to determine the econometric relationship between variables. The results verifies the negative relationship between freight revenues and vessel disposal decisions.
\end{abstract}

\section{Özet}

Gemi söküm pazarı, denizcilik pazarındaki arz fazlasını dengelemeye yardımcı olur. Bazı faktörler bu süreci hızlandırırken, bazı faktörler ise bu süreci yavaşlatır. Navlun gelirleri, bu süreci doğrudan etkileyen en önemli faktörlerden biridir. Çünkü yüksek navlunların olduğu hareketli piyasalarda eski ve köhne gemiler bile karlı bir şekilde operasyonlarını yürüterek piyasada kalmayı başarırlar. $\mathrm{Bu}$ doğrultuda bu çalışma, navlun gelirleri ile gemiyi söküme gönderme kararları arasındaki ilişkiyi ekonometrik olarak inceleyerek mevcut literatüre katkıda bulunmayı amaçlamaktadır. Söküme gönderilen toplam gemi tonajı ve Baltık Kuru Yük Endeksi değişkenleri seçilmiştir ve 1985 ile 2015 arasındaki yıllık veriler modelde kullanılmıştır. Veri kısıtı nedeniyle Baltık Kuru Yük Endeksi navlun gelirlerinin bir temsilcisi olarak seçilmiştir. Söküme gönderilen toplam gemi tonajı ise söküme gönderme kararlarının bir sonucu olarak ele alınmıştır. Korelasyon ve regresyon analizleri değişkenler arasındaki ekonomik ilişkiyi saptamak için kullanılmıştır. Sonuçlar navlun gelirleriyle söküme gönderme kararları arasındaki negatif ilişkiyi doğrulamaktadır.

\footnotetext{
${ }^{1}$ Research Assistant, Dokuz Eylül University, Maritime Faculty, e-mail: abdullah.acik@deu.edu.tr, Corresponding Author

${ }^{2}$ Associate Professor, Dokuz Eylül University, Maritime Faculty, e-mail: ozlen.baser@deu.edu.tr
}

Makale Geliş Tarihi: 7 Aralık 2017

Makale Kabul Tarihi: 22 Aralık 2017 


\section{Introduction}

Maritime transport has a vital role in world economic interactions. It makes possible to reach commodities that are produced in far-flung geographic locations in the world at an acceptable cost. In 2015, totally 10.047 million tons of cargo was transported by maritime transportation, and 2.951 million tons of this amount consist of main bulk commodities (RMT, 2016). Therefore, maritime sector contains a lot of players and investors, and necessitates big amount of capitals. So it has its own characteristics that are worth examining.

In general, the life cycle of a ship goes through four main markets, shipbuilding market, freight market, sale and purchase market and demolition market (Stopford, 2009:177). The activities in the other 3 markets are affected by the situation in freight market. Koopmans (1939) investigated the determinants of freight rates in terms of a model of supply and demand. If the supply exceeds demand, freight rates fall, but if the demand exceeds supply, freight rates rise.

Demand for the ship reflects the need for carrying capacity while demand for maritime transport is determined by the demand of the consumers of the goods. The demands of such consumers also lead to the demand for bulk cargo transportation. This indicates that the maritime transport service providers have little control over shipping demand (McConville, 1999). Because shipping is a derived demand from the demand for goods carried (Branch and Robarts, 2014:183). These situation forms sector-specific uncertainties that lead to a constant cyclicality in the market (Erol and Dursun, 2016).

As Porter (1990) remarked, the nature of competition and the return on capital are driven by five competitive forces in any industry whether it is domestic or international. These are threat of new entrants, threat of substitutes, the bargaining power of suppliers, bargaining power of buyers and rivalry among the existing competitors. Little control on demand expressed by McConville (1999) does not mean bargaining power of shipowners remains continually low. There are continuous cyclical movements in different lengths in the maritime sector throughout the history (Metaxas, 1988). Throughout these cycles the bargaining power that Porter (1990) mentions constantly changes hands in accordance with supply and demand balance in the sector. If the bargaining power of shippers in the market increases in parallel with increase of supply, some of the ships go out of play (Buxton, 1991). The consequence is engaged in the demolition market. Uneconomic ships are sent to the scrapping (Grammenos, 2010:249). As a result, after a point, a higher freight rate occurs when the increase in the number of ships going out is higher than the increase in the number of newly built ships (Randers and Göluke, 2007), and so the cycle continues constantly (Stopford, 2009:105). For these reasons, maritime transportation is a very risky economic and financial sector (Erol and Dursun, 2016).

Theoretical background of the demolition market is slightly rich in literature but econometric analysis of the market is limited. Moreover, the studies in this area have been mostly examined on the basis of steel industry, scrap prices and individual behaviors. No study is encountered that examined the tonnage sent to the demolition, which is a concrete product of demolition market's theoretical infrastructure. In this context, aim of this study is contributing to the existing literature 
by examining the relationship between freight revenues and tonnage that are sent to the demolition market. As a result this study is aimed at investigating this theoretically established situation.

The reminder of this study is organized as follows. Section 2 exhibits general situation of demolition market in the world based on leading countries. Section 3 mentions the importance and balancing role of the demolition market in the shipping cycle. After it is tried to explain why shipowners send their ships to demolition market in section 4, research model is established in accordance with the literature. Section 5 introduces the methodology of the study and the data used. Section 6 discusses the findings and estimation results related to the forecasting model. Section 7 concludes with an implementation summary.

\section{Demolition Market in the World}

The shipbreaking market in the world is concentrated in a small number of countries. These countries are Bangladesh, India, Pakistan, China and Turkey. Shipbreaking activities had been implemented in other geographical regions in the past but these activities has shifted through time. Stopford (2009) explained the primary reasons for these shift through time as search for lowest labor costs and high regional demand for steel. So nowadays the demolition industry is confined in developing countries where these conditions are met. In 2016, 28.9 million gross tons of ships were scrapped in the world. The first 6 countries in this industry are India, Bangladesh, Pakistan, China, Turkey, and respectively 9.9, 9.2, 5.2, 3.1 and 1 million gross tons of ships were scrapped in these countries (UNCTAD, 2017). The shares of these countries in total demolition activities is shown in Figure 1 as a percentage.

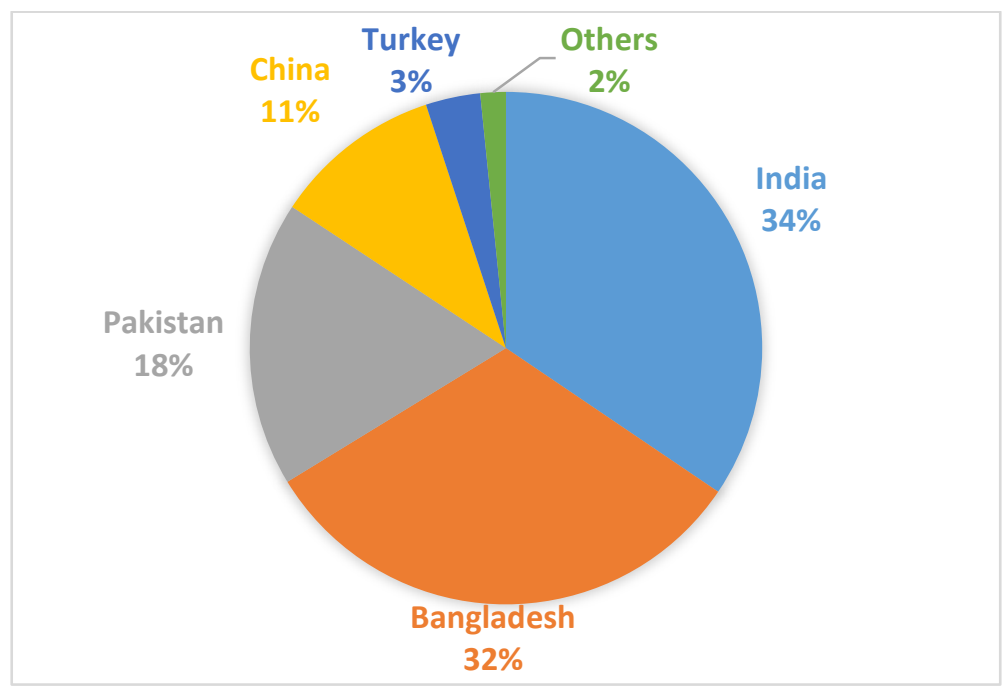

Figure 1: Distribution of Scrapped Tonnage by Main Scrapping Countries in 2016 Source: UNCTAD

The major players in demolition market are developing countries. So ship demolition market is seen as an important field of employment and income source. Sarraf et al. (2010) 
indicated that the ship demolition market contributes significantly to the domestic growth in these economies. Also Mikelis (2013) argued that the sector is vital for economic growth of 5 nations besides domestic steel production.

Shipbreaking activities in Turkey are made exclusively in Aliağa and carried out by 22 companies with contributions of 10 thousand people in employment. In this region, mostly dry cargo ships and platforms are scrapped. Also many iron and steel producers are located close to this region (IMEAK, 2016).

The ship demolition market presents important opportunities for economic growth for developing countries. But there is more than that. Demolition market acts as the balancing lever in times of ship oversupply (Jugović et al., 2015).

\section{The Role of Demolition in the Shipping Cycle}

There are many factors that influence the maritime shipping market. Stopford (2009) revealed 5 factors that influence demand and 5 factors that influences supply for maritime transport. The factors influence the demand are world economy, international maritime trade, average achieved profit, political events and transport costs. The factors that influence the supply are world fleet and its productivity, shipbuilding, shipbreaking and freights.

Most economists accept that freight rates are determined by interaction of supply and demand. Change in freight rates causes a shortage or a surplus of tonnage which triggers an increase or a decrease in freight rates in turn. If the demand exceeds supply, freight rates up and market responds by investing more new ships. On the contrary if supply exceeds demand, freight rates down and owners start to scrap uneconomic ships (Grammenos 2010:249). When the pace of sending ships to the demolition market is faster than receiving ships from newbuilding market, oversupply is reduced. This will cause a new market balance at higher freight rates (Randers and Göluke, 2007).

This relationship between supply and demand continues in a cycle throughout history. The first attempt to explain this cycle was the shipping cycle theory (Metaxas, 1988). Traditionally these cycles consists of rejuvenation, eudemonia, recession and crash stages. In rejuvenation stage freight rates increase after ship supply has considerably decreased. There is a decrease on number of laidup vessels so a balance occurs between supply and demand. Sentiments about the market become increasingly positive, so both second-hand vessel and scrapping prices increase. In eudemonia stage the shipping market has reached now at high levels. Also ships earn two or three times more than their ship operational costs. Second-hand prices exceed book value as came true in the previous years. Orders for newbuildings rise, so new vessels are delivered with a significant delay. In recession stage there is a surplus ship capacity, so recession occurs. Inefficient ships are laid-up because of decrease on freight rates. Demolition prices for old ships decreases to market levels because of increase on number of the ships that are sent to the demolition. In crash stage ship capacity exceeds demand because of delivery of ordered ships incrementally. Sentiments in the market turn negative direction and this situation expedites the market crash. Second-hand prices of 
the vessels decrease in parallel with newbuilding prices (Talley, 2012:213). The fall in demand for maritime transport also indirectly reduce the freight rates, increases the amount of ships that are laid-up and sent to the scrapping (Taylor, 1976).

When the statistical structure of the shipping cycles was examined, it was determined that there were 22 cycles between 1741 and 2007. The average of these cycles is 10.4 years, and the longest cycle lasted 20 years and the shortest cycle lasted 2 years (Stopford, 2009:105). The balance points constantly change according to the supply and demand interaction.

Buxton (1991) modeled the role of scrapping in the balance by figure below. When there is a surplus tonnage on supply side of the market, uneconomical ships are sent to the demolition. Also apart from that, entrance of newbuilding ships downs freight rates to the real low levels because of their fuel efficient hulls and machineries. This accelerates the scraping of older tonnage.

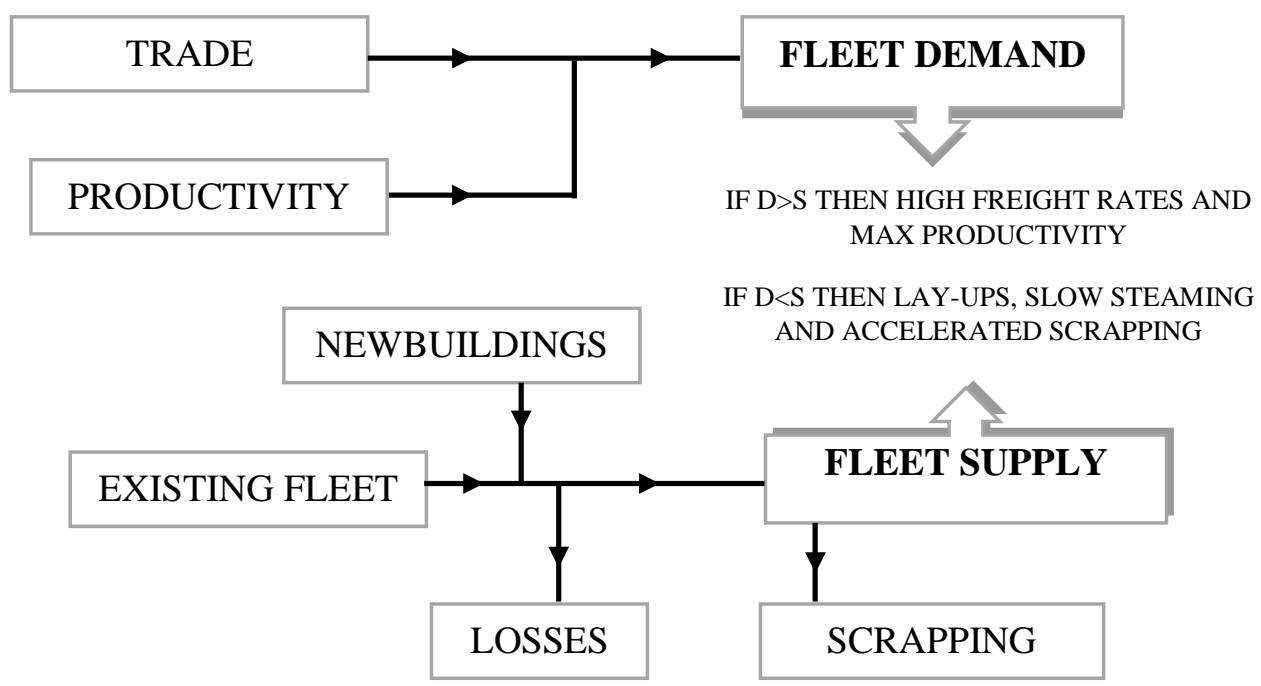

Figure 2: The Role of Scrapping in the Supply Demand Balance Source: Buxton 1991

The growth rate of merchant fleet depends on the balance between deliveries of new ships and deletion of fleet in the form of ships that are sent to the demolition or lost at sea (Jugovic, 2015). Ships are not immortal, so shipowners are obliged to dispose of them by selling second hand or demolition market. At this point they must decide when and which market they should dispose. This decision depends on some factors.

\section{Decision for Demolition}

The activity level in the demolition market fluctuates as well as freight market. There is no fixed age for ships to be sent to demolition. The economic life of a vessel is linked to the freight level and the income expected over the rest of the vessels technical life (Grammenos, 2010:221). In 
addition to wide fluctuations in the total amount of ships scrapped each year, the median age of the ships that are scrapped has wide variations (Buxton, 1991).

There are steady reasons for variations of disposal age. There are three elements that influence the theoretical disposal age of ships. These are economic obsolescence, physical obsolescence and political obsolescence. Economic obsolescence refers that ships are physically sound but they are rendered uneconomic by introduction of new efficient ships into the market. Physical obsolescence refers that ships are dilapidated in hull or machinery and not worth repairing. Political obsolescence refers that ships are unable to trade owing to flag discrimination, or inability to meet special regulatory requirements (Evans, 1989).

If the owner faces with declining profitability although he has exhausted cost-cutting measures, he has a number of choices:

i. Continue trading in the hope of improved markets

ii. Lay-up the ship, again in the hope of better times

iii. Convert, either to alternative trades, or modernize, e.g. re-engine

iv. Sell second-hand

v. Scrap.

The last two options offer a quick return depend on existing market conditions. The first three options are likely to generate negative cash flow for the next few years. The owner must make his own judgement. If he believes that future markets are likely to improve, he may choose keeping his vehicle by first three options. Otherwise he can choose last two options and generate quick return (Buxton, 1991). At this point formation of demolition prices in the market is vital for decisionmaking process.

Scrap prices depends on some key factors. Mikelis (2007) provided some key statistical analysis and indicated that a possible positive correlation between freight markets and demolition prices. In addition to that he argued that demolition prices are also affected by supply of vessels, internal demand for steel and the differences in environmental and labor costs of demolition markets. Merikas et al. (2015) touched upon a similar point and investigated the relationship between steel industry and demolition industry. He argued that ship recycling industry is one of the main supplier of steel industry and thus steel industry affects the ship recycling industry. Also he supported the view that when the freight market conditions are favorable, high demolition prices are offered to ship owners to attract their ships to demolition market. Knapp et al. (2008) explained this situation by examining the relationship between freight levels and decision to send a ship to demolition market. According to his research, freight levels have negative effects on the decision to send a ship to demolition market. Higher freight rates trigger the earnings. Even inefficient, aged and obsolete vessels can be operated profitably. So shipowner will be reluctant to sell the ship to the demolition market as long as it is profitable. Thus there is a negative relationship between freight levels and number of ships that are scrapped.

The Figure 3 below helps to explain this negative relation. The amount of the ship tonnage that were sent to demolition had reached its minimum levels when the freight rates had reached the highest levels ever. 
As Knapp et al. (2008) mentioned, high freight levels have negative effects on decision to send a ship to the demolition market. Thus, before a shipowner starts to evaluate the option to send a ship to the demolition market, freight market conditions must deteriorate firstly. When market conditions deteriorate and market freight rates do not allow to profitable operations, evaluation of shipowner starts for sending a ship to demolition market (Karlis et al, 2016).

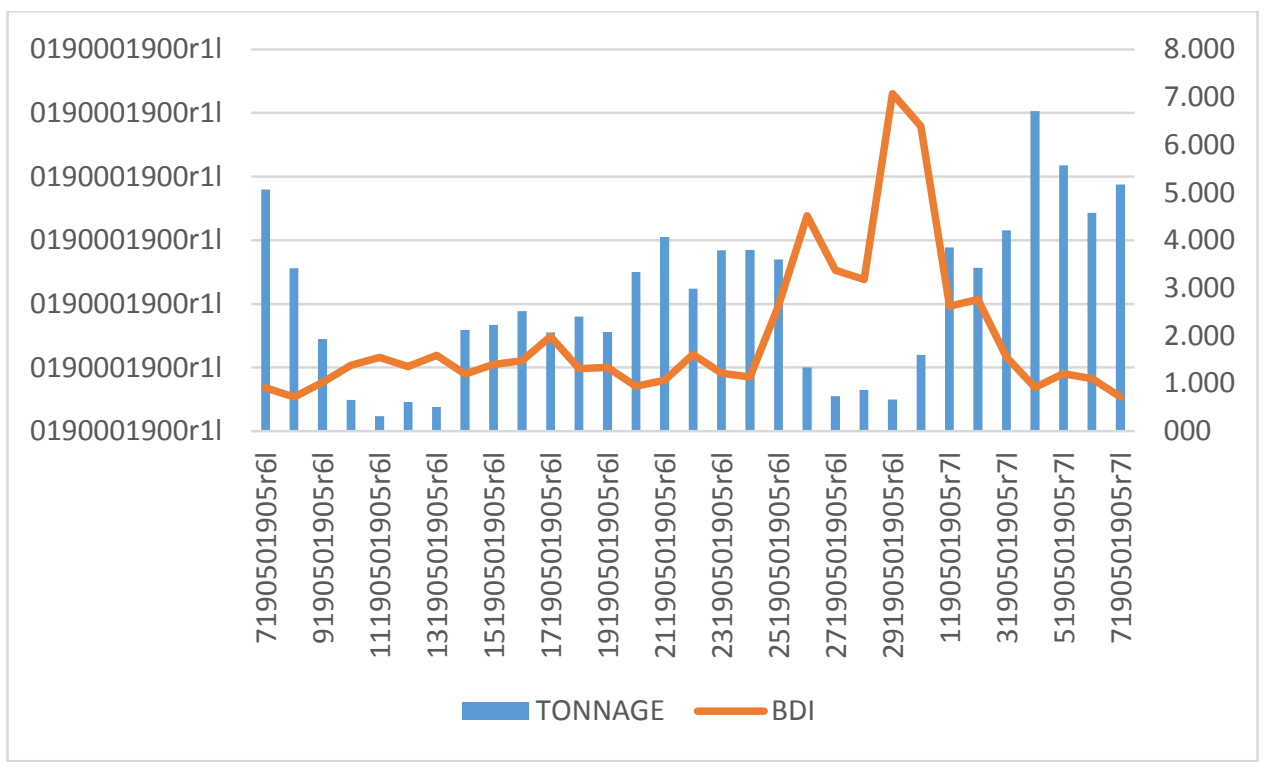

Figure 3: Tonnage Sent to Scrapping and Baltic Dry Index Source: Bloomberg, Athenian Shipbrokers

Scrap prices are connected with the demand for steel (Merikas et al, 2015). This relationship of these variables is result of usage of scrapped steel in the steel production process (World Coal Association, 2016). When the freight levels are low, demand for steel will be also low. Consequently, scrap prices in the demolition market will be reduced. This is a big dilemma for shipowners, because they looks for a high scrap prices when demand for steel and scrap prices follow a downward trend (Karlis et al, 2016).

In the light of such information, this paper investigates the effects of freight revenues on ship disposal decisions. The direction and degree of relationship will be examined by econometric models.

\section{Methodology}

Pearson's correlation analysis and logarithmic linear regression model are used for analysis of this study. Pearson's correlation coefficient R, a measure of the strength and direction of the linear relationship between two variables, is defined as the (sample) covariance of the variables divided by the product of their (sample) standard deviations. The absolute value of Pearson correlation coefficients is no larger than 1 . Correlations equal to 1 or -1 correspond to data points 
lying exactly on a straight line (Chang, 2014:78). Formula of the Pearson correlation is presented below.

$$
r=\frac{n\left(\sum X Y\right)-\left(\sum X\right)\left(\sum Y\right)}{\sqrt{\left[n\left(\sum X^{2}\right)-\left(\sum X\right)^{2}\right]\left[n\left(\sum Y^{2}\right)-\left(\sum Y\right)^{2}\right]}}
$$

After the Pearson's correlation coefficient is obtained by (1), t statistics of coefficient should be calculated to determine whether coefficient significant or not. Calculated t value by (2) is compared with table values of t-distribution. If it is bigger than critical value, this means the coefficient is significant.

$$
t=\frac{r \sqrt{n-2}}{\sqrt{1-r^{2}}}
$$

Another analysis of the study, regression analysis is concerned with the study of the dependence of one variable on one or more other variables. The dependent variable are tried to be explained by the explanatory variables. The results that gained after analysis are used for estimating and/or predicting the mean or average value of the former in terms of the known or fixed values of the latter (Gujarati, 2004:18). Simple model of the regression equation is presented at (3). $Y_{i}$ is the dependent variable of the equation, $\hat{\beta}_{1}$ is the predicted constant of the equation, $\hat{\beta}_{2}$ is the predicted coefficient of the $X_{i}$ which is the independent variable in the model. At lastly $\hat{u}_{i}$ is the residuals that cannot be explained by existing model. (4) presents the calculation of the coefficient of independent variable and (5) presents calculations of constant coefficient. And significances of the coefficients are calculated by (6).

$$
\begin{array}{r}
Y_{i}=\hat{\beta}_{1}+\hat{\beta}_{2} X_{i}+\hat{u}_{i} \\
\hat{\beta}_{2}=\frac{n \sum X_{i} Y_{i}-\sum X_{i} \sum Y_{i}}{n \sum X_{i}^{2}-\left(\sum X_{i}\right)^{2}} \\
\hat{\beta}_{1}=\bar{Y}-\hat{\beta}_{2} \bar{X} \\
\operatorname{tstat}\left(\hat{\beta}_{1}\right)=\hat{\beta}_{1} / \operatorname{se}\left(\hat{\beta}_{1}\right) \\
\operatorname{tstat}\left(\hat{\beta}_{2}\right)=\hat{\beta}_{2} / \operatorname{se}\left(\hat{\beta}_{2}\right) \\
\ln Y_{i}=\ln \beta_{1}+\beta_{2} \ln X_{i}+u_{i}
\end{array}
$$

Log-log regression model (7) is used for our study. One attractive feature of the log-log model, which has made it popular in applied work, is that the slope coefficient $\hat{\beta}_{2}$ measures the elasticity of $\mathrm{Y}$ with respect to $\mathrm{X}$, that is, the percentage change in $\mathrm{Y}$ for a given (small) percentage 
change in X (Gujarati, 2004:176). Also using logarithmic values in data makes them continuous series. Theoretical model of the study is tried to be explained in the next section.

\subsection{Research Model}

The one of the main indicators that represents freight earnings is Baltic Dry Index. The BDI is an index covering dry bulk shipping rates. The BDI provides an assessment of the price of moving the major raw materials by sea. The index takes account 26 shipping routes measured in time charter and voyage basis (Geman, 2008:181). . Since its establishment, the BDI has become one of the foremost indicators on the cost of shipping and an important barometer on the volume of worldwide trade and manufacturing activity (Lin, 2013). So Baltic Dry Index is selected as a representative of freight revenues in this study.

As mentioned before, freight rates are determined by interaction of supply and demand. Change in freight rates causes a shortage or a surplus of tonnage which triggers an increase or a decrease in freight rates in turn. If the demand exceeds supply, freight rates up and market responds by investing more new ships. On the contrary if supply exceeds demand, freight rates down and owners start to scrap uneconomic ships (Grammenos 2010:249). The research model of the study is shown below.

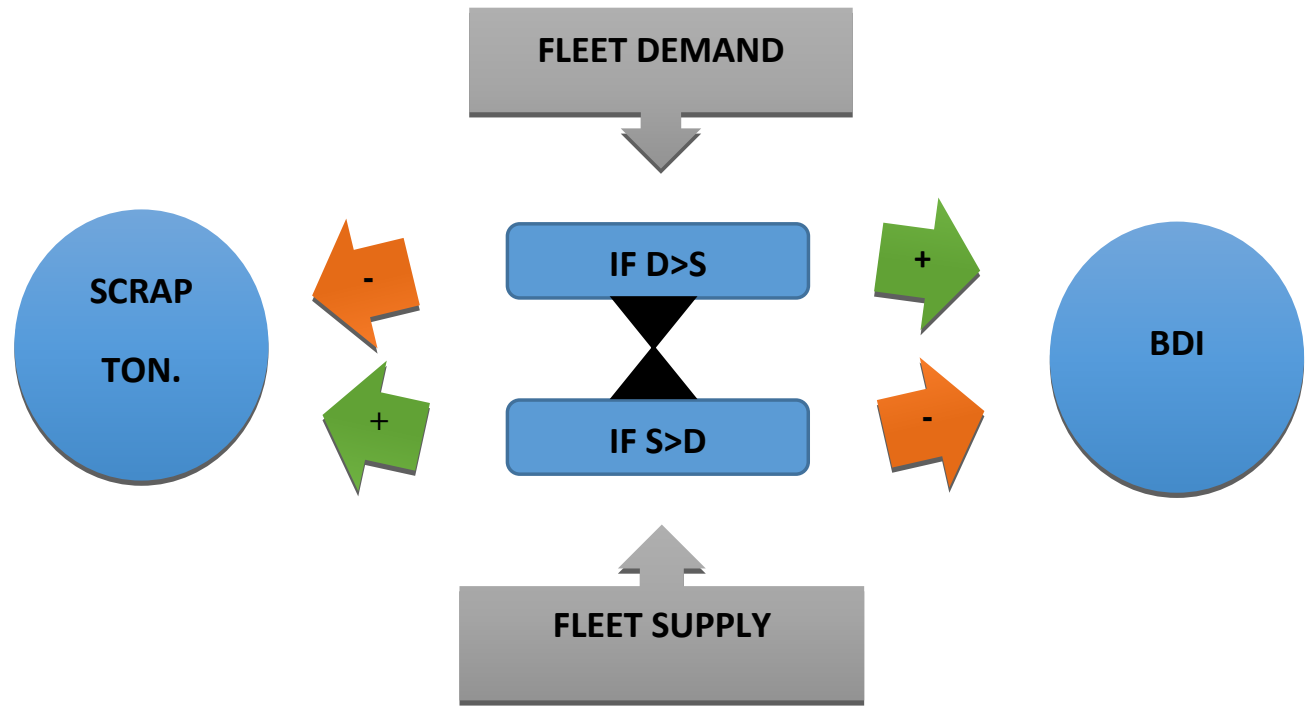

Figure 4: Research Model of the Study

Supply and demand of fleet interacts each other and a market freight level determined in the market. This level increase or decrease according to market conditions. As seen at the Figure 4, if demand is bigger than supply, freight rates increases and the amount of ship number that are sent to the demolition market is decreases. As explained by Knapp et al. (2008), even inefficient, aged and obsolete ships can be operated profitably in high freight rates. On the contrary if supply is bigger 
than demand, freight rates decreases and uneconomic ships cannot perform their operations. Shipowner have to choose one of options that are presented by Buxton (1991). In this situation generally ships are sent to the demolition market. In the light of such information, there is a negative relation between freight revenues and the tonnage that are sent to the demolition. Aim of this study is testifying the direction and degree of this relationship.

\subsection{Data}

The TONNAGE variable refers to annual total scrapped shipping amount in terms of deadweight tons. It includes all kind of ships scrapped. BDI variable refers to annual average of daily Baltic Dry Index. Descriptive statistics of these variables are presented below. The data totally consist of 31 observation and cover the years from 1985 to 2015.

Table 1: Descriptive Statistics of Baltic Dry Index and Indian Demolition Prices

\begin{tabular}{|l|c|c|c|c|c|c|}
\hline & TONNAGE & BDI & InBDI & InTONNAGE & $\Delta$ InBDI & $\Delta$ InTONNAGE \\
\hline Observations & 31 & 31 & 31 & 31 & 30 & 30 \\
\hline Mean & 20855806 & 1974.399 & 7.392025 & 16.60187 & -0.00775 & 0.000694 \\
\hline Median & 18900000 & 1385.051 & 7.233493 & 16.75467 & -0.02102 & -0.025276 \\
\hline Maximum & 50300000 & 7070.256 & 8.863652 & 17.73352 & 0.833368 & 1.431318 \\
\hline Minimum & 2350000 & 715.3715 & 6.572802 & 14.66993 & -0.89294 & -1.084913 \\
\hline Std. Dev. & 12630564 & 1538.167 & 0.584509 & 0.808874 & 0.392704 & 0.544246 \\
\hline Skewness & 0.320169 & 2.113439 & 0.998108 & -0.784475 & 0.134464 & 0.352739 \\
\hline Kurtosis & 2.333750 & 6.865496 & 3.342229 & 2.552536 & 2.957445 & 3.501328 \\
\hline Jarque-Bera & 1.102983 & 42.37772 & 5.298420 & 3.438191 & 0.092667 & 0.936285 \\
\hline Probability & 0.576090 & 0.000000 & 0.070707 & 0.179228 & 0.954724 & 0.626164 \\
\hline
\end{tabular}

Source: Bloomberg, Athenian Shipbrokers

When the graphical display of the variables is examined, the negative relation between variables can be seen at the Figure 5. The variables generally move reverse directions. The next section, econometric relationship between variables are tried to be explained to support our hypothesis. 
Ekonomi, Politika \& Finans Araştırmaları Dergisi, 2017, 2(2): 96-112

Journal of Research in Economics, Politics \& Finance, 2017, 2(2): 96-112

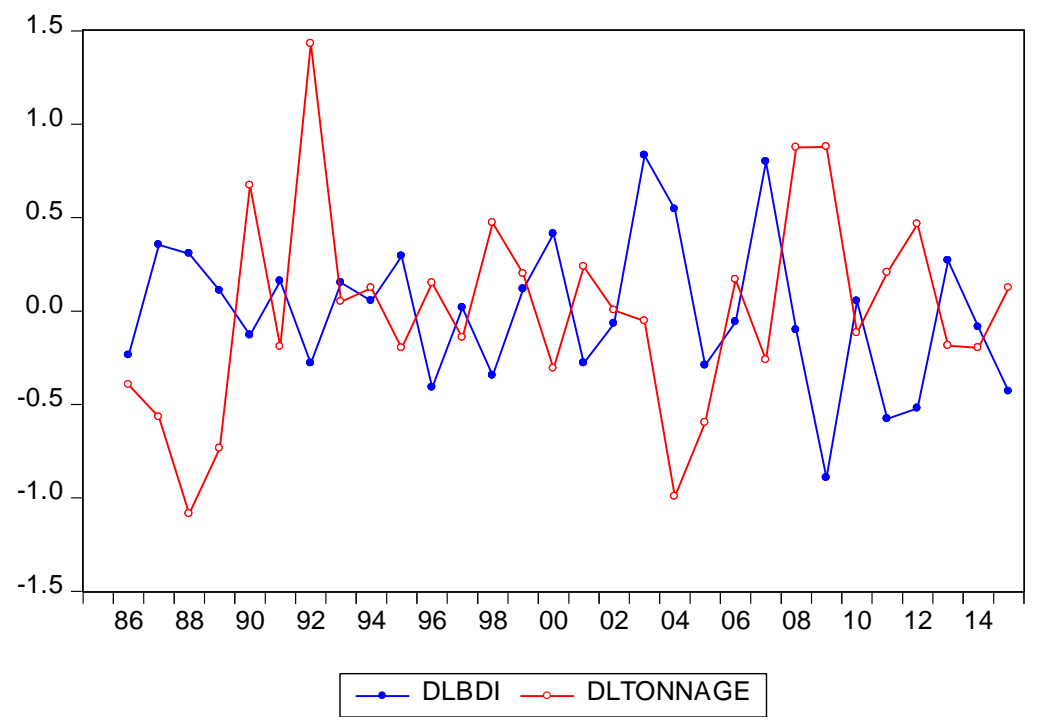

Figure 5: Differentiated Logarithmic Values of Baltic Dry Index and Total Tonnage Sent to Scrapping Source: Bloomberg, Athenian Shipbrokers

\section{Findings and Discussion}

The variables that will be used to construct our econometric models must be stationary in order to avoid spurious regression problems. Therefore, our analysis begin by using a unit root test. Augmented Dickey-Fuller (ADF) test is generally used and accepted test that is used to determine whether a unit root exists or not. The null hypothesis of the test is that the original series has a unit root which means series are non-stationary. If the absolute values are smaller than the reported critical values, we fail to reject the null hypothesis which means tested series is non-stationary. The ADF Unit Root test results are shown at Table 2. Level of significance is taken 5\%. According to test results both of the variables are stationary at their first difference. So lnBDI and lnTONNAGE are integrated of order one, I(1).

Table 2: ADF Unit Test Results

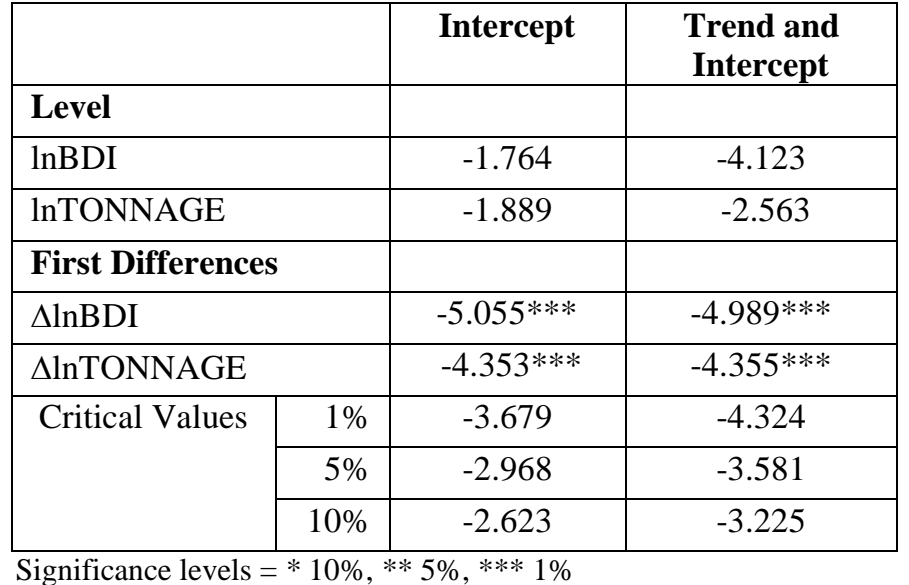


A. Açık \& S.Ö. Başer, "Gemiyi Söküme Gönderme Kararlarıyla Navlun Gelirleri Arasındaki İlişki”"

To determine the degree and direction of the relationship by quantitative method, a correlation analysis is implemented. Pearson correlation is used on normally distributed variables. As seen at Table 1, differentiated logarithmic values of variables are normally distributed. According to the analysis result that is presented at Table 3, there is a medium-degree negative significant correlation between Baltic Dry Index and the total tonnage of ships that are sent to the demolition. This result helps to support our hypothesis, but it is not enough to determine explanatory power of BDI over demolished tonnage. Then a logarithmic linear regression equation is estimated.

Table 3: Pearson Correlation Analysis between Variables

\begin{tabular}{|c|c|c|}
\hline & $\Delta \operatorname{lnBDI}$ & $\Delta \operatorname{lnTONNAGE}$ \\
\hline \multirow{2}{*}{$\Delta \operatorname{lnBDI}$} & 1.0000 & \\
& ----- & \\
\hline \multirow{3}{*}{$\Delta \ln$ TONNAGE } & ----- & 1.0000 \\
& $(-3.52811$ & ---- \\
& $0.0015 * * *$ & ---- \\
\hline
\end{tabular}

Regression equation is estimated as freight revenue is independent variable and tonnage is dependent variable. Equation is as follow:

$$
\operatorname{lnTONNAGE_{i}}=\ln \beta_{1}+\beta_{2} \ln B D I_{i}+u_{i}
$$

Converted stationary variables are used in the equation and the results is presented at Table 4. According to the results, constant is insignificant and independent variable is significant. Because tstatistics of the BDI is bigger than its table value. F statistics value which is greater than its table value shows the significance of the whole model. Also probability values test the $\mathrm{H}_{0}$ hypothesis that refers the insignificance. Smaller than 0.05 probabilities reject the insignificance. When the coefficients of the variables are examined, it can be commented that $1 \%$ increase on freight revenues decreases $0.76 \%$ the total tonnage of the ships that are sent to the demolition market. However, explanatory power of the model is 0.30 which indicates that changes in freight revenues explains $30 \%$ of change in demolished tonnage.

Table 4: Regression Model Equation Results

\begin{tabular}{|l|c|l|l|l|}
\hline Dependent Variable: $\Delta \operatorname{lnTONNAGE}$ \\
\hline Variable & Coefficient & Std. Error & t-Statistic & Prob. \\
\hline \multicolumn{1}{|c|}{ C } & -0.005268 & 0.084150 & -0.062606 & 0.9505 \\
\hline \multicolumn{1}{|c|}{$\operatorname{lnBDI}$} & -0.768909 & 0.217902 & -3.528685 & $0.0015^{* * *}$ \\
\hline R-squared & 0.307815 & F-statistic & 12.45162 \\
\hline Adjusted R-squared & 0.283094 & Prob (F-statistic) & 0.001463 \\
\hline
\end{tabular}

Significance levels $=* 10 \%, * * 5 \%, * * * 1 \%$ 
Also some diagnostic tests should be implemented to determine whether regression results are consistent or not. These tests are autocorrelation test, serial correlation test, heteroscedasticity test and normality test. These tests are implemented to residuals of the equation.

The first tests are autocorrelation and serial correlation tests. 16 lags are selected and Q-stats test is implemented to determine autocorrelation problem. Probabilities of the all lags are bigger than the critical value which is 0.05 . This means that the hypothesis $\mathrm{H}_{0}$ cannot be rejected, which assumes there is no autocorrelation problem. Another test that is used for analyzing serial correlation is Breusch-Godfrey Serial Correlation LM Test. Default hypothesis of this test is there is no serial correlation problem. As seen at the Table 5, default hypothesis is cannot be rejected which means there is no serial correlation problem.

Table 5: Breusch-Godfrey Serial Correlation LM Test Results

\begin{tabular}{|l|l|l|l|}
\hline F-statistic & 0.655508 & Prob. F(2,26) & 0.5275 \\
\hline Obs*R-squared & 1.440095 & Prob. Chi-Square(2) & 0.4867 \\
\hline
\end{tabular}

White heteroscedasticity test is used for determination of changing variance. Default hypothesis of this test refers there is no heteroscedasticity problem. According to the test results, $\mathrm{H}_{0}$ cannot be rejected as seen at Table 6 .

Table 6: White Heteroskedasticity Test Results

\begin{tabular}{|l|l|l|l|}
\hline F-statistic & 0.040141 & Prob. F(2,27) & 0.9607 \\
\hline Obs*R-squared & 0.088939 & Prob. Chi-Square(2) & 0.9565 \\
\hline Scaled explained SS & 0.101097 & Prob. Chi-Square(2) & 0.9507 \\
\hline
\end{tabular}

Distribution of residuals should be normal according to diagnostics test suppositions of regression equation. Histogram normality test is used for testing distribution of residuals, according to the results, probability of the Jarque-Bera statistics is bigger than critical value that refers $\mathrm{H}_{0}$ cannot be rejected. Distribution of residuals are normal based on results that can be seen at Table 7 .

Table 7: Histogram Normality Test Results

\begin{tabular}{|l|l|}
\hline Skewness & 0.370588 \\
\hline Kurtosis & 3.609791 \\
\hline Jarque-Bera & 1.151483 \\
\hline Probability & 0.562288 \\
\hline
\end{tabular}

The correlation results show that there is a significant medium-degree negative directional relationship exists between freight earnings and demolished tonnage. As earnings increases, 
tonnage sent to the demolition decreases. This supports theoretical background of the demolition market that are presented previous sections. Then logarithmic regression equation is estimated to investigate elasticity of variables. According to results, $1 \%$ increase on revenues causes $0.77 \%$ decrease on scrapped tonnage. The model is significant and explains nearly $30 \%$ of the changes in dependent variables. This explanatory power is relatively low, this may stem from non-divided tonnage data into the subsectors because of limitations of the data.

Ship demolition helps to balance over supply in shipping market. Also it pushes down freight rates in depressed market conditions by eliminating inefficient and costly ships (Buxton, 1991). These eliminated ships become sources for other industries. Demand for steel increases when world economy is buoyant. So the need for raw materials increases for steel production. Scrapped steel is also a source of steel production (Merikas et al. 2015). So, ship demolition prices and freight rates move together generally (Mikelis, 2007). Therefore, shipowners are between a rock and a hard place for this situation. Because when the freight levels are high, demolition prices are high too, and when the freight levels are low, demolition prices are low as well. But they expect high scrap prices when demand for steel and scrap prices follow downward trend (Karlis et al, 2016). Although these studies are seen in different areas, they show an integrity with this study. Because decisions to disposal a ship is related to position of freight revenue to its alternative option. This alternative option is demolition prices, which are often linked to events that developed outside of the maritime industry, such as steel industry. As Knapp et al. (2008) mentioned, high freight revenues have negative effects on vessel disposal decisions. As a result, this study has also been integrated with these studies by examining the effects of freight revenues on the decision to send ships to demolition market on tonnage basis. The increase in freight revenues leads to a decrease in the scrapped tonnage of ships. Another study conducted with the same data and model has not been encountered in the literature.

\section{Conclusion}

In depressed market conditions, shipowners have a few options. These are continuing for trading even it is albeit at a loss, laying-up ship, modernizing it, selling second hand and sending it to the demolition. If the owner needs quick cash, he can choose last two options to generate hot money. Sending ship to demolition is the interest of this study.

This study aims to contribute existing literature by presenting an econometric analysis of the relationship between freight revenues and ship disposal decisions. BDI was selected as an indicator for freight revenues due to the data constraint. Total tonnage sent to the scrapping was taken as a result of the decision to send ships to disposal. The significant negative relationship between the two variables was confirmed by both the correlation and the regression analysis results. $1 \%$ increase on freight revenues causes $0.77 \%$ decrease on total tonnage that is sent to the demolition market. The results found were consistent with the literature reviewed throughout the study and they were complementary to existing literature. Due to the sudden revivals in economic activities, the rate of increase in demand for maritime transport is higher than the rate of increase in supply for maritime transport. As a result of that freight revenues increase because of the interaction between supply and 
demand sides. So even those vessels with very high operating and maintenance costs catch an environment where they can continue their profitable operations. At this point serious reductions in the number of ships that are sent to the demolition occur.

The demolition tonnage data used in this study is collected from free publications. So its frequency is annual and number of observation is limited. Also this demolition tonnage data are not divided into subsectors.

Further researches may use data that has more frequent observations and tonnage that are sent to the demolition data may be divided into subcategories such as dry bulk, liquid bulk and general cargo ships. Also representatives of supply and demand in the maritime sector may be added to the model. 
A. Açık \& S.Ö. Başer, "Gemiyi Söküme Gönderme Kararlarıyla Navlun Gelirleri Arasındaki İlişki”

\section{References}

Athenian Shipbrokers, S. A. (2016). Monthly Report. Total Demolition Amounts. Retrieved March, 9, 2016.

Bloomberg Data Platform, Baltic Dry Index, Accessed 15.08.2016, https://www.bloomberg.com/professional Branch, A. E. and Robarts, M. (2014). Branch's Elements of Shipping. Routledge.

Buxton, I. L. (1991). The Market for Ship Demolition. Maritime Policy \& Management 18 (2): 105-112.

Chang, M. (2014). Principles of Scientific Methods. New York: CRS Press

Erol, E. and Dursun, A. (2016). Düzensiz Hat Denizyolu Taşımacılığının Piyasa Yapisi ve Değerlendirilmesi. Uluslararasi İktisadi ve İdari Incelemeler Dergisi, 16: 153-170.

Evans, J. (1989). Replacement, Obsolescence and Modifications of Ships. Maritime Policy and Management 16(3): 223-231.

Geman, H. (2008). Risk Management in Commodity Markets: From Shipping to Agricultures and Energy. UK: Wiley

Grammenos, C. (2010). The Handbook of Maritime Economics and Business. Great Britain: MPG Books

Gujrati, D.N. (2004). Basic Econometric, (4th Ed.). New York: The McGraw-Hill Companies.

Hampton, M.J. (1991). Long and Short Shipping Cycles, (3rd Ed). Cambridge: Cambridge Academy of Transport.

IMEAK, Ship Demolition Industry, February 2016

Jugović, A., Komadina, N. and Hadžić, A. (2015). Factors Influencing the Formation of Freight Rates on Maritime Shipping Markets. Scientific Journal of Maritime Research 29: 23-29.

Karlis, T. and Polemis, D. (2016). Ship Demolition Activity: A Monetary Flow Process Approach. Scientific Journal of Maritime Research 30: 128-132.

Koopmans, T. C. (1939). Tanker Freight Rates and Tankship Building: An Analysis of Cyclical Fluctuations. De erven F. Bohn nv.

Lin, F. and Sim, N. C. S. (2013). Trade, Income and the Baltic Dry Index. European Economic Review 59: 118.

Lun, Y. V., Lai, K. H. and Cheng, T. E. (2010). Shipping and Logistics Management. London: Springer.

McConville J (1999). Economics of Maritime Transport, Theory and Practice. London: Whiterby.

Merikas, A., Merika, A. and Sharma, A. (2015, January). Exploring Price Formation in the Global Ship Demolition Market. In 2015 Annual Meetings.

Metaxas , V. (1988). Principles of Maritime Economics. Athens: Papazisis.

Mikelis NE. (2007). A Statistical Overview of Ship Recycling. In: International symposium on maritime safety, security and environmental protection, Athens.

Mikelis, N. (2013). Ship Recycling Markets and the Impact of the Hong Kong Convention. Paper presented at the International Conference on Ship Recycling, World Maritime University, Malmo, Sweden, April 2013.

Porter, M. (1990). The Competitive Advantage of Nations. New York: Free Press.

Randers, J. and Göluke, U. (2007). Forecasting Turning Points in Shipping Freight Rates: Lessons from 30 Years of Practical Effort. System Dynamics Review 23(2-3): 253-284.

RMT (Review of Maritime Transport 2016), UNCTAD

Saraf, M., Stuer-Lauridsen, F., Dyoulgerov, M., Bloch, R., Wingfield, S., \& Watkinson, R. (2010). Ship breaking and recycling industry in Bangladesh and Pakistan. The World Bank Washington.

Stopford, M. (2009). Maritime Economics, 3rd ed.. London: Routledge.

Talley, W. (2012). The Blackwell Companion to the Maritime Economics. UK: Blackwell Publishing Ltd.

Taylor, A. J. (1974). The Dynamics of Supply And Demand in Shipping. Dynamica 2 (2): 62-71. 
Ekonomi, Politika \& Finans Araştırmaları Dergisi, 2017, 2(2): 96-112

Journal of Research in Economics, Politics \& Finance, 2017, 2(2): 96-112

UNCTAD (United Nations Conference on Trade and Development) Statistics, "Demolition Tonnage by Countries", Accessed 20.06.2017,

http://unctadstat.unctad.org/wds/ReportFolders/reportFolders.aspx?sCS_ChosenLang=en

World Coal Association, "How is Steel Produced?", Accessed 10.06.2016),

https://www.worldcoal.org/coal/uses-coal/how-steel-produced 